Agro-Science Journal of Tropical Agriculture, Food, Environment and Extension Volume 8 Number 3 September 2009 pp. 175 - 179

ISSNTII9-7455

\title{
ECONOMIC ANALYSIS OF ARTISANAL FISHING AT RIVER NIGER ONITSHA, ANAMBRA STATE, NIGERIA
}

\author{
Anyanwu $^{1}$, D.C. Mkpado $^{2}$ M. and Ohaka ${ }^{1}$ C.C. \\ ${ }^{1}$ School of Agriculture and Vocational Studies, Alvan Ikoku College of Education, Owerri, \\ Nigeria \\ ${ }^{2}$ Department of Agricultural Economics \\ University of Nigeria, Nsukka, Nigeria
}

\begin{abstract}
This study investigated the economics of artisanal fishing along River Niger in Onitsha North Local Government Area of Anambra State, Nigeria. A total of 80 fishermen were randomly selected for the study. Data were collected by the use of structured set of questionnaires. Four research questions guided the study. Results of profitability analysis showed that an average fisherman makes a gross margin of

A96002.29 per month in a year. The problems of artisanal fish production included inadequate cold rooms/storage facilities, high cost of fuel and spare parts as well as extreme unfavorable weather condition. The study recommends among others; subsidizing inputs such as engine boats and the spare parts and use of cooperative efforts to build cold rooms with good storage facilities.
\end{abstract}

Keywords: Artisanal fishing; economic analysis; river Niger; Nigeria

\section{INTRODUCTION}

It is a fact that Nigeria is blessed with abundant natural and human resources. Water bodies are among the important natural resources bequeathed to Nigeria by nature. Fishing activities constitute the traditional occupation of communities possessing these water sources such as lakes, streams, oceans and rivers especially along River Niger and Benue, which tri-set the country. The hunting, catching and marketing of edible freshwater and ocean fishes largely dominate fishing industry in Nigeria. The artisanal fishermen in Nigeria, however, total about half a million and approximately 42 percent of this number are part-time fishermen who also engage in other economic activities such as farming and tailoring. Besides, the predominant craft used in artisanal fisheries are dugout and wooden plank type of canoes or a combination of both. (F.A.O., 1985; Mabwaonuku 1998)). The total number of canoes in 1990 was about 215,060 out of which less than 20 percent was powered by outboard engine (F.D.F, 1995). The dugout canoes are the Nigerian traditional canoe, which can be carved out of a single log or timber. The length varies from 3.5-7.0 meters. The ratio of the average beam and length is 1:6. This subsector is characterized by low capital outlay, low operating cost, low application of technology and intensive labour demand as well as high post harvest losses, varying from 35-45 percent (Tobor, 1990). Despite these problems, this sub- sector contributed about 96.2 percent of the total fish output from 1990-1994 (F.D.F., 1995).

Fish is a major source of animal protein in Nigeria. NIOMR (1998) noted that insufficient supply of fish has contributed to malnourishment in children as well as adults and has led to a decrease in life span of certain individuals. The development plan of 1991-1997 may have targeted solving this problem by setting a production target of half million tonnes (Tobor, 1993). Bada (2005) noted that fish supply from three sub-sectors - artisanal, aquaculture and industrial on the average had not met 30 percent of the required fish demand in the last 20 years. Statistics have shown that artisanal fish production has continued to be the major source of fish to Nigeria over the past two decades (FDF, 1995).

Artisanal fishing accounted for more than $80 \%$ of total fish production in Nigeria for twenty years from $1985-2005$; while aquaculture accounted for less than $8 \%$ of the production and industrial fishing fluctuates with a pick of $13.9 \%$ and minimum of $5.0 \%$ for the period under review (Bada (2005). Even though artisanal fish production is the main stay of Nigerian domestic fishing industry, researchers have paid little attention to the experiences of the artisanal fishermen. Ugwumba et al. (2006) studied catfish seed production with wooden vat and concrete type of hatcheries; while Ofuoku and Ideh (2005) investigated fingerling and table fish production 
between cooperative and non-cooperative farmers in Delta State. They found that majority of the cooperative fish farmers were on large scale table fish and fingerling production while majority of non-cooperative fish farmers engaged in smallscale table fish and fingerling production.

This study was therefore articulated to investigate the socio-economics of artisanal fish farming in Anambra State, Nigeria. The specific objectives are to (1) examine the socio-economic characteristics of the artisanal fisher folks at the shore of River Niger in Anambra State, (2) determine the cost and returns of artisanal fish industry in the State, and (3) identify the problems encountered by the fisher folks and proffer solutions for improving the artisanal fishing enterprise.

\section{RESEARCH METHODOLOGY \\ The Study Area}

The study was conducted in River Niger in Onitsha North Local Government Area of Anambra State. The State lies between latitudes $6^{0} 44^{1}$ and $5^{0} 44 \mathrm{~N}$ longitude $6^{0} 36^{1}$ and $6^{0} 72 \mathrm{E}$. Its land area is $4844 \mathrm{sqkm}$. The population in the Local Government according to National Population Census of 2006 was 124,942 people including fishermen. Two fishing communities were purposively selected, namely Ogbaru and Umuleri, which are known for their fishing activities. The communities are located at Onitsha about $25 \mathrm{~km}$ away from Onitsha main town. It is characterized by a tropical climate with average temperature of $28^{\circ} \mathrm{C}$. The men are predominantly second part of artisanal fishermen and women are fish processors. The communities have good access roads linking them to Ose and Onitsha main market, which are the major markets for captured fish. A study of Ogbaru and Umuleri show that the communities are blessed with arable farm lands and the fishermen embrace farming as their secondary occupation. The cultivated crops are yam, cassava, maize, vegetables and coconut and so on. The dwellers are close to the River and on the other side of the road are swampy lands for farming during the dry season when fishing intensity is very low.

\section{Population and Sampling Procedure}

Purposive sampling was used to select Ogbaru and Umuleri which are communities that engage more in the enterprise. Random sampling was used to select 80 fishermen from the two communities afore selected in Onisha North LGA. The list of fishermen in these chosen communities formed the frame from which a sample of 40 fishermen was randomly selected in Ogbaru out of 50 and 40 from Umuleri out of 50 making a sample size of 80 fishermen.

\section{Instrument for Data Collection}

Data used for this study were obtained from primary and secondary sources. The primary data was a cross sectional data obtained through the administration of a set of structural questionnaire and interview schedules. The information sought included educational background, family size, fishing inputs, revenue from fish and so on. The secondary data were obtained through extensive library research.

\section{Method of Data Analysis}

The tools used in this study were descriptive statistics, and gross margin analysis. Objective (1) and (3) were achieved using descriptive statistics such as mean, percentage and frequencies. Objective (2) was achieved using cost benefit and gross margin analysis. These were used to determine the cost and expenses incurred during production as well as the profitability of the business. The variable costs include costs of fuel, feeding, and maintenance, cost of ice, bait, twine rope, hooks and spare parts. The benefits refer to those revenue, which help farmers achieve their objectives of a project. In this case, the benefit is the returns/profit from the enterprise. The profit was calculated according to Arene, (2002) as

\begin{tabular}{lll}
\multicolumn{1}{c}{$\Pi=$} & $\mathrm{TR}-\mathrm{TC}$ \\
Where: & & \\
income) & & Net Profit (Net farm \\
$\mathrm{TR}$ & $=$ & Total Revenue \\
$\mathrm{TC}$ & $=$ & Total Cost \\
The second part of Objective (2) was
\end{tabular}
achieved using gross margin analysis. Gross margin is the difference between total revenue and total variable cost (TVC). Since the interest of the researcher is on the short-term run cost and revenue, the fixed capitals is not included in the computation of gross marginal analysis. Total gross margin was obtained based on the method outlined by Arene, (2002)

$$
\begin{aligned}
& G M=\frac{\sum T R-\sum T V C}{\text { One Month }} \\
& \text { Where: GM }=\quad \text { Gross Margin } \\
& \text { TR }=\quad \text { Total Revenue } \\
& \text { TVC }=\quad \text { Total Variable Cost. }
\end{aligned}
$$

\section{RESULTS AND DISCUSSION Socio-Economic Characteristics of the Respondents}

The socio-economic characteristics of the fishermen are highlighted in table 1. Male respondents had a frequency of 80 representing 100 percent while female had a frequency of zero. Therefore, the total sample was all male, hence the name fishermen. The youths within the 
Anyanwu, D.C. Mkpado M. and Ohaka C.C.

Table 1: Socio-economic Characteristics viz Sex, Age, Educational Status, Marital Status, Household Size, Secondary Occupation and Years of Fishing experience of the Respondents

\begin{tabular}{|c|c|c|c|}
\hline \multicolumn{2}{|c|}{ Socio-economic characteristics of the respondents } & \multirow{2}{*}{$\begin{array}{l}\text { Frequency } \\
80\end{array}$} & \multirow{2}{*}{$\begin{array}{l}\text { Percentage \% } \\
100\end{array}$} \\
\hline Sex: & Male & & \\
\hline & Female & 0 & 0 \\
\hline \multirow[t]{5}{*}{ Age:( in years) } & $10-30$ & 7 & 8.75 \\
\hline & $31-40$ & 26 & 32.50 \\
\hline & $41-50$ & 29 & 36.25 \\
\hline & $51-60$ & 18 & 22.50 \\
\hline & Above 60 & 0 & 0 \\
\hline \multirow[t]{4}{*}{ Education status: } & No primary school & 12 & 15 \\
\hline & FSLC & 25 & 31.3 \\
\hline & SSCE & 41 & 51.3 \\
\hline & Tertiary institution & 2 & 2.5 \\
\hline \multirow{2}{*}{ Marital status: } & Single & 4 & 5.0 \\
\hline & Married & 76 & 95.0 \\
\hline \multirow[t]{3}{*}{ Household size } & $1-3$ persons & 19 & 23.75 \\
\hline & $4-6$ persons & 55 & 68.75 \\
\hline & $7-8$ persons & 6 & 7.5 \\
\hline Secondary: & Farming & 45 & 53.3 \\
\hline \multirow[t]{7}{*}{ Occupation: } & Mat making & 9 & 11.3 \\
\hline & Mason & 1 & 1.3 \\
\hline & Boat renting & 9 & 11.3 \\
\hline & Palm wine tapping & 5 & 6.3 \\
\hline & Basket making & 7 & 8.8 \\
\hline & Net making & 3 & 3.8 \\
\hline & Trading & 1 & 1.3 \\
\hline \multirow{6}{*}{$\begin{array}{l}\text { Fishing experience } \\
\text { (in years) }\end{array}$} & 10 yrs below & 8 & 10 \\
\hline & $11-21$ & 32 & 40 \\
\hline & $22-30$ & 24 & 30 \\
\hline & $32-40$ & 13 & 16.25 \\
\hline & $42-51$ & 3 & 3.75 \\
\hline & 51 above & 0 & 0 \\
\hline
\end{tabular}

Source: Field Survey, 2006; Total number of observations $=80$

range of 10-30 years participated least actively in fish production and accounted for 8.75 percent of respondents. This may be attributed to migration to the urban areas for white-collar jobs. Those within the age ranges of $31-40$ and $41-50$ participated more actively in fish production constituting $32.5 \%$ and $36.25 \%$ respectively. The fishermen within the ranges of 51-60 years and above were the less active in fish production. They constituted $22.5 \%$ of the respondents. May be due to their old age they could no longer engage more in fishing.

The figures in the table 1 also show that most of the fishermen had secondary school education. Fifty one and thirty one percent of the fisher men had secondary and primary education respectively. The overall picture is that more than $70 \%$ of the fishermen attended one level of education or another so, they would be able to understand the importance and the application of new improved technologies involved in fish production. The sum of percentage of those that attended primary school $(31.3 \%)$ and higher school $(2.5 \%)$ was less than those that had secondary education $(41 \%)$. Only a few (2\%) felt they should attend higher education if their focus is to be fulltime fishermen, this will help in the business as they could introduce innovations in the production due to their educated faculties.

The maximum household had 4-6 children. They represent $68.78 \%$ of respondents, while households with 1-3 and 7-8 children had constituted $23 \%$ and $7.5 \%$ respectively. With respect to marital status of the fishermen, $95 \%$ of them were married while $5 \%$ were not married.

It was observed that the fishermen engaged in other occupations as well as fishing. These activities/occupations are carried out when fishing is low, precisely during the months of July and August when the river is not conducive for fishing. The survey showed that $53.3 \%$ of the fishermen engage in farming. The majority of the fishermen were within this category; this may be due to the presence of arable farmland. Boat renting and mat making were other sources of income for the fishermen.

The figures in the table 1 also show that the fishermen started the enterprise at a very early age. Out of a total sample of 80 fishermen $40 \%$ had fishing experience of 11-21 years while $30 \%$ had 22-30 years of experience, $16 \%$ and $3.7 \%$ had 32-40 years and 42-51 years of fishing experience respectively. 
Economic Analysis of Artisanal Fishing at River Niger

Table 2: Hours Spent in Fishing per Day

\begin{tabular}{lcc}
\hline Hours spent/day & Frequency & Percentage \\
\hline $1-5$ & 29 & 36.25 \\
$6-10$ & 27 & 33.75 \\
$11-15$ & 24 & 30 \\
\hline Total & 80 & 100 \\
\hline Source: Field Survey, 2006 & &
\end{tabular}

Cost and Return of Artisanal/Fish Mongers per Week

Table 3: Cost and return of Artisanal/fish mongers production per Month

\begin{tabular}{|c|c|}
\hline Items & Amount (\$) \\
\hline Canoe & 7701.88 \\
\hline Cost of cast net & 354.38 \\
\hline Training cost & 148.50 \\
\hline Engine cost & 153000.00 \\
\hline Cost of hooks & 339.13 \\
\hline Cost of spare parts & 2157.50 \\
\hline Cost of rope & 349.38 \\
\hline Total fixed cost & 164050.77 \\
\hline Depreciation cost (at 5 years or 60 months depreciation with zero salvage value) & 32810.15 \\
\hline Fuel & 3409.99 \\
\hline Oil & 2186.61 \\
\hline Feeding & 601.88 \\
\hline Ice & 1062.56 \\
\hline Bait & 60.00 \\
\hline Hiring of gears & 89.56 \\
\hline Total variable cost & $7,410.60$ \\
\hline Total cost & 40220.75 \\
\hline Sales & 100467.51 \\
\hline Gifts & 1555.75 \\
\hline Family consumption & 1389.63 \\
\hline Total revenue & $103,412.89$ \\
\hline Gross margin & 96002.29 \\
\hline Net farm income & 63192.14 \\
\hline
\end{tabular}

Source: Field Survey, 2006.

\section{Hours Spent in Fishing per Day}

Table 2, indicated that the majority of the respondents spent 1-5 hours in fishing, while those who spend 6-10 and 11-15 hours accounted for $33.75 \%$ and $30 \%$ respectively

Table 3, showed a gross margin of \$6002.29 and net enterprise income of \#63192.14. Major cost items included engine boat, canoe and spare parts.

\section{Limiting Problems in the Fishing Enterprises} Table 4 shows the distribution of fishermen according to the problems they encountered in their fishing activities. All the fishermen were of the view that cold room and other storage facilities were major problems. These would increase fish spoilage which will reduce their income.

Other problems encountered by the fishermen are lack of credit facilities and poor funding. The credit facilities, which they needed, could aid them to get more of fishing nets, outboard engine and boats. This will improve fishing activities and enable them adopt new technologies. 
Table 4: Limiting Problems in the Fishing Enterprises

\begin{tabular}{lcc}
\hline Limiting problems & Frequency* & Percentage \% \\
\hline Cold room and other storage facilities & 80 & 29.0 \\
Funding and credit problem & 80 & 29.0 \\
High cost and scarcity of fuel & 29 & 10.5 \\
Marketing problems & 18 & 6.5 \\
High cost of fishing materials and spare parts & 48 & 17.4 \\
Cold weather & 21 & 7.6 \\
\hline Total & 276 & 100 \\
\hline Source: Field Survey, 2006; *Multiple choice responses recorded & &
\end{tabular}

\section{CONCLUSIONAND} RECOMMENDATION

The study noted that all the respondents were male folks. Traditionally, this occupation has been named after men. The study also found out that majority of the male fell within the active working age bracket of 31 to 50 years. Educational qualification of majority of the respondents consisted of first school leaving and senior secondary school certificates. It was also reported that $95 \%$ of the respondents were married. The enterprise was profitable. Major problems included inadequate storage facilities, scarcity of fuel, marketing problems and high cost of fishing materials

The study recommended as follows:

1. since this venture is profitable, ablebodied youth should embrace this business instead of staying idle.

2. The Government and non -government organization can provide service centers where fishermen could lease canoes and buy spare parts at a reduced rate.

3. Government should also assists in building of ultra modern cold rooms and storage facilities to enhance fish production.

4. Fishermen could form cooperatives to handle problems associated with marketing and storage facilities.

\section{REFERENCES}

Ajakaiye, M.B. (1990). "Agricultural Lending for Rural Development: Problems and Prospects" NACB Digest 2. (3): 22-23.

Alfred, Y.C. (1999). Aquaculture Economics: Basic Concept and Method of Analysis. England West Press, Boulder, Coloradahelm London.

Arene, C. J. (2002), Economic Analysis of Agricultura and Rural Development Projects,

Fulladu Publishing Co. Nsukka, Nigeria.

Bada, A.S. (2004). "Investment Potentials in Homestead Catfish Farming in Concrete Tanks". A paper presented during the 2004 African Farm Management Association Conference, Abuja, Nigeria.
Bada, A.S. (2005). "Strategies for Bridging the Supply-Demand Gap in Fish Production in Nigeria". Proceedings of the $19^{\text {th }}$ Annual Conference of the Farm Management Association of Nigeria, pp. 329-337.

F.A.O (1985). Food and Agricultural Organization: Report of the $13^{\text {th }}$. Session of the European inland Fishery Advisory Commission, Demark No. 3011 pp. 42.

F.D.F (1995). Fisheries Statistics of Nigeria. Federal Department of Fisheries, Lagos pp 13-14

FOS (1997) Federal Office of Statistics; Lagos, Nigeria

Kalu, O.J (2002). Basic Principles of Economics for Agricultural Prospects and Policy Analysis, Nsukka. Pnee Publisher pp. 542.

Mabowonku A.F. (1998). Fisheries in Nigeria Economy. The Challenges Ahead. The Journal of West African Fisheries, 11 (1): 18-23.

NPC (2006) National population commission: Census Report, Abuja Nigeria

Ofuoku, A.U. and V. Ideh (2005). "Comparative Analysis of Cooperative and Noncooperative Fish Farmers in Delta Central Agro-Ecological Zone of Delta State" Proceedings of the $19^{\text {th }}$ Annual Conference of Farm Management of Nigeria, pp. 390-394.

Tobor J.G. (1990) Fisheries Statistical Survey of Nigeria. National Institute for Maritime Research (NIOMR), Lagos.

Tobor, J.G. (1993). The Fish Industry in Nigeria: Status and Potential for Self Sufficiency in Fish Production. National Institute for Maritime Research (NIOMR) Lagos, p. 54.

Ugwumba, C.O.A., Ugbaja, M.J. and E.C. Orji (2006). "Sustainable Catfish Seed Production in Anambra State". Proceedings of the $40^{\text {th }}$ Conference of the Agricultural Society of Nigeria, pp. 511-513 